\title{
DESAIN KANDANG TERNAK BABI DI PERKOTAAN
}

\author{
Redempta Wea $^{1}$; Aholiab Aoetpah ${ }^{2}$; dan Bernadete Barek Koten ${ }^{3}$ \\ $\left.{ }^{1}\right)$ Jurusan Peternakan Politeknik Pertanian Negeri Kupang, \\ Email: wearedempta@yahoo.co.id
}

\begin{abstract}
ABSTRAK
Usaha pemeliharaan babi merupakan usaha berpotensi ekonomi dan banyak dipelihara oleh masyarakat, namun menjadi masalah jika pemeliharaanya dilakukan pada daerah perkotaan. Solusinya adalah dibangun perkandangan yang baik. Tujuan pengabdian adalah menghasilkan desain kandang yang dilengkapi tempat penampungan limbah yang baik di perkotaan. Metode kegiatan adalah penyuluhan tentang manajemen pemeliharaan ternak babi, demplot desain perkandangan, pemberian ransum menggunakan limbah dapur dan pakan komplit sebagai contoh untuk mengetahui pertumbuhannya, serta penyebaran kuisioner guna mengetahui dampak pelaksanaan kegiatan, pendampingan, dan evaluasi kegiatan. Hasil kegiatan yang dilakukan diawali dengan rapat bersama antara pemilik ternak babi dan pemerintah setempat (RT), kemudian dilanjutkan dengan penyuluhan tentang manajemen pemeliharaan ternak babi, pembangunan kandang sesuai desain pada 3 lokasi mitra, pembangunan penampungan limbah pada 8 lokasi mitra dan masyarakat serta pembagian EM4 untuk meminimalisir bau. Dampak dari kegiatan ini adalah tersedianya kandang dan tempat penampungan limbah sehingga 100\% peternak babi sudah mengalirkan limbahnya sehingga polusi bau yang ditimbulkan menjadi berkurang serta tumbuhnya kesadaran masyarakat untuk memberi makan babi dengan mencampurkan limbah dapur dan bahan pakan lainnya. Kesimpulannya, tingkat ketercapaian kegiatan $100 \%$ untuk perkandangan dan dampak polusi yang sudah berkurang menjadi $90 \%$ serta disarankan pemeliharaan selanjutnya pada lokasi lain dan menggunakan juga produk EM4 untuk menghilangkan bau.
\end{abstract}

Kata Kunci : Limbah dapur, Ransum, Demplot, Penyuluhan 


\section{PENDAHULUAN}

Usaha peternakan khususnya ternak babi memiliki potensi ekonomi yang sangat besar untuk dikembangkan. Dikatakan demikian karena usaha ternak ini sudah dilakukan oleh masyarakat khususnya masyarakat Nusa Tenggara Timur (NTT) secara turun temurun walaupun di daerah perkotaan yang padat penduduknya. Hal ini didukung oleh keadaan sosial budaya masyarakat NTT yang beragama non muslim, pasaran ternak di NTT cukup baik, serta secara sosial budaya masyarakat NTT selalu menggunakan ternak babi dalam setiap perayaan adat dan agama serta (Wea, 2007).

Woha (2001) dalam Moata (2004) menyatakan bahwa daerah NTT memiliki kemarau panjang (8-9 bulan) dan musim hujan singkat (3-4 bulan). Kondisi alam ini sangat berpengaruh terhadap pemeliharaan ternak babi di NTT karena ketersediaan bahan pakan sebagai sumber pakan ternak babi juga berkurang. Hal inilah yang menyebabkan peternak babi memanfaatakan limbah dapur dan limbah rumah makan sebagai pakan ternak babi sehingga produktivitas ternak rendah. Kenyataan ini terjadi di daerah Kelurahan Oesapa Kecamatan Kelapa Lima Kota Kupang Nusa Tenggara Timur (NTT) khususnya pemelihara ternak pada dua kelompok yakni kelompok Umat Basis Ratu Pemersatu Ilahi (KUB RPI) dan Kelompok Umat Rayon 21.

Kelurahan Oesapa merupakan salah satu kelurahan dalam Kecamatan Kelapa Lima yang terletak di daerah kerendahan dan memiliki jumlah penduduk yang padat yakni 5.228 orang per $\mathrm{km}^{2}$ dengan luas wilayah $4,37 \mathrm{~km}^{2}$ artinya terdapat 1196,34 orang/ $/ \mathrm{km}^{2}$ serta memiliki jumlah penduduk dengan kisaran umur masing-masing adalah 0-4 tahun 2180 orang, 5-14 tahun 3671 orang, 15-44 tahun 15856 orang, 45-64 tahun 1969 orang, dan $\geq 65$ tahun 482 orang (Statistik kabupaten/kota, 2012). Berdasarkan data statistik tersebut diketahui bahwa jumlah penduduk terbesar berada dalam kisaran umur produktif $73,79 \%$ sedangkan anak-anak $24,22 \%$ dan orangtua 1,99\% yang sangat rentan terhadap adanya polusi dan pencemaran lingkungan.

Namun, walaupun memiliki daerah yang padat penduduk namun masyarakat peternak mendapat mutu pelayanan dari pemerintah yang baik. Salah satu bentuk pelayanan adalah adanya 
bantuan dari dinas social terhadap pengktan perekonomian msayarakat, yakni bantuan usaha yang diberikan sesuai keinginan masyarakat, yakni bibit ternak babi misalnya. Selain itu kehidupan masyarakat mitra di Desa Oesapa sangat menjunjung tinggi toleransi antar umat beragama karena tidak pernah terjadi pertengkaran antar agama walaupun berbeda suku maupun status sosialnya.

Masyarakat mitra peternak babi umunya bekerja sebagai seorang tukang, ojek, penjual sayur, bahkan ada yang berstatus janda yang harus menghidupi dirinya sendiri dan keluarga. Kenyataan ini mengindikasikan bahwa penghasilan merekapun pas-pasan sehingga harus mencari sumber pendapatan lain, salah satunya beternak babi. Namun karena penghasilan mereka yang pas-pasan sehingga usaha ternak dilakukan seadanya yang ditandai dengan perkandangan yang dibuat seadanya dari kayu, kemiringan lantai kandang tidak diperhatikan sehingga kandang becek dan menimbulkan penyakit, tidak memiliki tempat penampungan limbah tapi dibiarkan mengalir begitu saja bahkan ada yang disalurkan ke got pembuangan umum, serta pakan yang diberikan seadanya berasal dari limbah dapur dan rumah makan yang ditempatkan dalam rumah yang menimbulkan bau dan sarang lalat.

Dampak dari pemeliharaan ternak tersebut menimbulkan polusi bau dan pencemaran lingkungan terutama terjadinya kebecekan dan pencemaran tanah dan air tanah mengingat daerah Oesapa merupakan daerah kerendahan dengan sumber air tanah berupa sumur. Kenyataan ini menimbulkan protes dari masyarakat sekitar sehingga pada Tanggal 26 Desember 2014 diadakan rapat tingkat RT dan kelurahan serta diputuskan agar menutup usaha pemeliharaan ternak babi, namun kenyataannya peternak tetap memelihara ternak babi hingga sekarang.

\section{MASALAH}

Berdasarkan analisis situasi tersebut diketahui bahwa permasalahan prioritas yang terjadi pada kedua mitra peternak babi tersebut adalah tidak tersedianya tempat penampungan limbah dan tempat penyimpanan limbah dapur sebagai makanan ternak babi yang menimbulkan dampak terjadinya polusi dan pencemaran lingkungan serta berdampak luas bagi kehidupan masyarakat baik dari segi sosial, budaya, dan religi. Dikatakan demikian karena limbah yang tercecer tersebut menimbulkan pencemaran pada tanah dan jika dibuang ke saluran air umum menimbulkan bau 
dan polusi di pesisir pantai dan laut karena saluran tersebut akan bermuara di laut. Kenyataan ini menimbulkan kesenggangan sosial dan budaya serta dapat menimbulkan konflik dan kesenggangan dengan masyarakat muslim.

Pemeliharaan ternak babi tetap dilakukan oleh mitra dikarenakan ternak babi memiliki peluang untuk mendapatkan penghasilan dalam waktu yang cepat. Hal ini dikarenakan sebagian besar atau anggota mitra berpenghasilan pas-pasan dengan bersumber pada usaha ternak babi, penghasilan suami sebagai ojek, tukang, dan wiraswasta lain. Hal lain yang mendorong peternak tetap memelihara ternak babi adalah terdapatnya dukungan dari dinas sosial berupa bantuan peningkatan perekonomian masyarakat dalam bentuk bantuan bibit ternak babi.

Adanya dua sisi kepentingan yang berbeda antara pemerintah yang ingin mengatasi masalah pencemaran lingkungan dengan kepentingan anggota mitra sebagai sumber perekonomian yang mudah dan cepat mengindikasikan bahwa harus ada penyelesaian dari dua kepentingan ini. Salah satu solusi yang ditawarkan adalah pembangunan kandang yang memiliki tempat penampungan limbah dan tempat penyimpanan limbah dapur yang baik serta memberikan contoh pemberian ransum dengan menggunakan limbah dapur dan rumah makan.

\section{METODE}

Permasalahan prioritas mitra berupa limbah ternak berupa feces, urin, air cucian kandang, dan sisa-sisa pakan yang terbuang begitu saja karena tidak tersedianya tempat penampungan limbah ternak babi dan juga tidak tersedianya tempat penyimpanan limbah dapur dan rumah makan sebagai sumber makanan ternak babi menyebabkan terjadinya polusi berupa bau dan pencemaran lingkungan sekitar serta berdampak luas bagi kehidupan masyarakat sekitar baik dari segi sosial, budaya dan kepercayaan sehingga menimbulkan protes atau komplein dari masyarakat dan pemerintah setempat untuk menutup usaha. Namun disisi lain mitra juga menggantungkan hidupnya pada usaha ternak babi sebagai sumber untuk mendapatkan dana dalam waktu singkat. Oleh karena itu, adanya perbedaan kepentingan ini menghasilkan diskusi panjang antara mitra dan pengusul serta mengambil jalan keluar atau solusi dari masalah ini 
adalah mendesain kandang ramah lingkungan yang dillengkapi dengan tempat penampungan limbah dari kandang dan tempat untuk menyimpan limbah dapur dan rumah makan sebagai makanan ternak.

Metode pendekatan yang akan dilakukan terdiri dari tiga tahap yakni melaksanakan penyuluhan atau penyadaran, pelaksanaan demplot, dan pendampingan. Kegiatan yang dilakukan selalu didahului dengan melakukan pendekatan dan diskusi dengan anggota mitra.

\section{Prosedur Kerja}

Prosedur kerja yang dilakukan dalam merealisasikan tiga metode tersebut adalah:

1. Sebelum pelaksanaan kegiatan pengusul membagikan kuisiner pada masyarakat sekitar peternak guna mengetahui sikap atau respon masyarakat tentang pemeliharaan ternak babi yang dilakukan (bertujuan mendapatkan data dasar agar dapat mengukur dampak kegiatan IbM yang dilakukan)

2. Berdasarkan kuisioner yang dibagikan, tim dan mitra menghubungi pemerintah setempat guna mendapatkan izin dan dukungan dalam pelaksanaan kegiatan

3. Pengusul bersama mitra mendiskusikan tiga metode pendekatan yang akan dilakukan

4. Pengusul menyiapkan bahan yang akan disuluhkan tentang manajemen pemeliharaan ternak babi yang baik dari segi bibit, pakan, perkandangan, dan cara penanganan limbah yang baik serta dampak limbah jika tidak ditangani dengan baik.

5. Berdiskusi bersama tentang waktu penyuluhan dengan mitra, pemerintah setempat, dan masayarakat sekitar pemelihara ternak babi

6. Penyuluhan dilakukan dengan menggunakan alat bantu berupa leaflet materi penyuluhan serta penjelasan tentang desain kandang perkotaan serta menjelaskan tentang penggunaan limbah dapur dan rumah makan dalam ransum ternak babi

7. Demplot bersama mitra melalui pembangunan kandang yang terlebih dahulu sudah didiskusikan bersama mitra, masyarakat dan pemerintah, dimana pembangunan kandang contoh dilakukan pada 3 lokasi mitra dan pembangunan tempat penampungan limbah pada 8 lokasi mitra dan masyarakat. 
8. Demplot pencampuran ransum dan diberikan pada 2 ekor ternak sebagai contoh untuk diamati pertumbuhannya.

9. Melakukan pemeliharaan ternak babi yang menggunakan campuran ransum berbahan limbah dapur untuk mengetahui produktivitas ternak babi dengan menimbang bobot badan awal dan akhir pemeliharaan.

10. Kurang lebih dua bulan pelaksanan kegiatan pengusul membagikan kuisioner pada masyarakat sekitar untuk mengetahui sikap atau respon masyarakat terhadap kegiatan yang dilakukan.

11. Proses pendampingan dilakukan setiap minggu dengan cara selalu melakukan survey terhadap pelaksanaan pemeliharaan ternak dan berdiskusi tentang masalah lain seputar ternak babi berdasarkan pengetahuan dan pengalaman pengusul.

\section{Partisipasi Mitra}

Berdasarkan prosedur kerja dan rencana kegiatan yang dilakukan tersebut diketahui bahwa dalam setiap tahap kegiatan dari awal hingga akhir baik diskusi, pelaksanaan kegiatan penyuluhan dan demplot serta kegiatan pendampingan selalu melibatkan peranan mitra secara aktif dan melekukan pendekatan dengan pemrintah setempat dalam hal ini ketua RT. Ketua RT 13 RW 005 dan sekretaris RT 14 RW 005 Kelurahan Oesapa menyambut gembira kegiatan yang dilakukan dengan menyediakan lokasi penyuluhan yang bertempat di areal RT, membantu melakukan pendekatan dan surat menyurat kepada semua peternak babi sekitar untuk mengikuti penyuluhan yang dilakukan, serta melakukan pengecekan terhadap pengerjaan penampungan limbah dan kandag. Hal ini dikarenakan mitra kegiatan sebagai subyek pelaku dan penerima program kegiatan yang diharapkan akan menjadi contoh bagi masyarakat sekitar sehingga tidak terjadi lagi kesenggangan antara mitra, masyarakat sekitar, dan pemerintah setempat.

\section{Jenis luaran}

Jenis luaran yang telah disepakati bersama dalam pendekatan awal bersama mitra adalah desain kandang perkotaan dengan spesifikasi, sebagai berikut: 
1. Kandang dibangun dengan utara selatan agar mendapat sinar matahari yang baik dan berbentuk empat persegi panjang serta bertipe tunggal dengan luas lantai kandang ternak babi diperuntukan bagi pemeliharaan ternak babi dewasa disesuaikan dengan kebiasaan masyarakat yang memelihara ternak dari kecil hingga dewasa dan dijual sewaktu-waktu jika diperlukan.

2. Luas lantai kandang untuk babi dewasa $1,8 \mathrm{~m}^{2}$ /ekor, tempat makan dan minum 0,5 x 0,35 $\mathrm{m}$ (Eusebio, 1988), dan tinggi kandang 1,2 m. Luasan lantai demikian dapat menampung babi penggemukan dengan kisaran bobot badan (BB) dan jumlah yang dipelihara masing-masing adalah BB 10-25 kg 4-5 ekor, BB 25-45 kg 3-4 ekor, BB 45-70 kg 2-3 ekor, dan BB 70-100 kg 1-2 ekor.

3. Tempat makan dan minum terletak di bagian depan kandang dekat pintu masuk dan dibuat sedikit landai bagian dalamnya agar memudahkan babi mengambil makan dan air.

4. Lantai kandang dibuat bersemen kasar dengan tujuan agar lantai tidak licin dan ternak terhindar dari cedera karena terjatuh serta dibuat dengan kemiringan $15^{\circ}$ agar memudahkan dalam pembersihan kotoran kandang

5. Dinding tembok dan dibuat licin dengan tujuan menghindari terjadinya luka pada saat ternak babi menggaruk badan

6. Atap kandang terbuat dari seng cap gajah duduk

7. Pintu kandang dibuat dari besi dengan ukuran panjang $\pm 80 \mathrm{~cm}$ dan tinggi $80 \mathrm{~cm}$ yang terletak di bagian depan kandang dan bagian belakang tidak dilengkapi lubang pembuangan. Hal ini bertujuan menghemat lahan dan tenaga karena semua akses ke dalam kandang hanya melalui satu pintu di depan.

8. Lubang saluran antara kandang ke tempat penampungan dibuat dengan kemiringan $20^{\circ}$ berlantai semen dengan kedalaman $8 \mathrm{~cm}$ dan dibuat bercabang kedua arah tempat penampungan. Pada saluran cabang dibuat sekat yang bisa dibuka-tutup untuk membelokkan arah aliran ke tempat penampungan.

9. Tempat penampungan limbah dibuat dengan kedalaman $1,5 \mathrm{~m}$, panjang $1 \mathrm{~m}$, dan lebar $1 \mathrm{~m}$ serta dibagi menjadi dua bak agar dapat dilakukan penggantian penggunaan bak ketika bak yang lainnya telah penuh. 
10. Dasar lantai dan dinding tempat penampungan dibuat bersemen agar tidak terjadi perembesan limbah yang menyebabkan polusi pada air tanah sekitar.

11. Bagian atas tempat penampungan dibuat bertutup yang dapat dibuka sewaktu-waktu. Hal ini bertujuan agar jika tempat penampungan sudah penuh maka dapat dibuka dan atau dibiarkan menjadi padat agar dapat diambil dan digunakan menjadi pupuk, sehingga jika bak yang lain juga telah penuh dapat kembali menggunakan bak bersangkutan secara bergantian.

12. Tempat penyimpanan makanan ternak asal limbah dapur dan rumah makan, dibuat bersambungan disamping kandang dengan ukuran panjang 1,0 m x lebar $35 \mathrm{~cm}$ x tinggi 70 $\mathrm{cm}$.

Selain luaran tersebut dihasilkan juga luaran berupa laporan dan artikel ilmiah yang dipublikasikan pada jurnal ilmiah pengabdian nasional serta dalam bidang jasa berupa transfer pengetahuan dalam bentuk penyuluhan dan demplot.

\section{HASIL DAN LUARAN YANG DICAPAI}

Berdasarkan metode kegiatan yang dijabarkan tersebut, maka pelaksanaan kegiatan yang dilakukan adalah:

1. Metode Penyuluhan:

Berdasarkan hasil kesepakatan antara tim IbM dengan pemerintah setempat dalam hal ini Ketua RT 013 RW 005 Kelurahan Oesapa Kecamatan Kelapa Lima Kota Kupang (kedua kelompok mitra berada dalam satu wilayah pemerintahan atau RT 013 RW 005 Oesapa), disepakati bahwa pelaksanaan IbM dilaksanakan di Lokasi atau di rumah Ketua RT dengan dasar pertimbangan bahwa kegiatan IbM yang dilakukan sesuai dengan program pemerintah dan ada beberapa anggota masyarakat yang menerima bantuan dari Dinas Sosial berupa bibit anak babi. Disamping itu respon yang baik dari pemerintah setempat dalam hal ini ketua RT 013 diwujud nyatakan dengan membuat dan menyebarkan undangan resmi tentang pelaksanaan penyuluhan pada semua anggota masyarakat peternak babi.

Penyuluhan yang diaksanakan tidak hanya melibatkan semua anggota mitra melainkan melibatkan semua anggota masyarakat dalam wilayah RT 013 yang memelihara ternak 
babi. Hal ini menyebabkan anggota masyarakat yang hadir bertambah jumlahnya yang mulanya 10 orang mitra menjadi 31 orang serta kegiatan dihadiri oleh juga oleh mahasiswa sebayak 3 orang. Hal ini dilakukan dengan harapan agar masyarakat peternak babi yang hadir walaupun tidak memelihara ternak babi maupun yang memelihara ternak babi namun belum mendapat bantuan pada saat IbM ini dapat juga memproleh tambahan informasi atau pengetahuan tentang cara beternak babi yang baik.

Pada saat pelaksanaan penyuluhan dilaksanakan peserta yang hadir menjadi bertambah atau berkembang bukan hanya pada wilayah RT 013 tapi juga melibatkan peternak dari RT 014 yang akhirnya berdasarkan keputusan rapat pada saat penyuluhan dilakukan juga mendapatkan bantuan pembangunan lubang pembuangan limbah ternak babi.

Kegiatan penyuluhan dilakukan pada hari Minggu, 21 Agustus 2016, yang didahului dengan sepatah kata dari sekretaris dilanjutkan dengan ketua RT 013 sekaligus membuka kegiatan penyuluhan secara resmi. Kegiatan selanjutnya adalah doa yang dipimpin oleh salah seorang peserta.

Setelah kegiatan doa selanjutnya kegiatan penyuluhan yang dilakukan oleh salah seorang nara sumber. Materi penyuluhan berupa manajamen pemeliharaan ternak babi mulai dari seleksi, pakan ternak, kesehatan, hingga pemasaran. Kegiatan selanjutnya adalah penyuluhan yang dilakukan oleh ketua tim IbM tentang desain perkandangan ternak babi. Desain kandang yang disuluhkan juga menyangkut kelebihannya sehubungan dengan terhindarnya air tanah yang tercemar karena limbah ternak babi dan terhindarnya limbah terbawa air pada saat hujan. Hal ini dikarenakan daerah Oesapa khususnya daerah sekitar RT 013 dan RW 014 merupakan daerah yang sering direndami air hujan. Pada saat penyuluhan juga dijelaskan tentang pengaruh letak lubang pembuangan baik pembuangan yang berasal dari WC manusia maupun dari kandang ternak yang dapat menyebabkan terjadinya penyebaran E. coli pada hampir semua wilayah Oesapa (berdasarkan hasil penelitian beberapa mahasiswa Fakultas Kesehatan Masyarakat Universitas Nusa Cendana). Sealin itu disuluhkan juga cara mengatasi polusi bau dari kandang babi dengan memperkenalkan produk EM4 baik sebagai bahan pencampur dalam air minum, makanan babi, maupun disemprotkan/disiram ke seluruh kandang sesuai dengan takaran yang telah tersedia. 
Kegiatan penyuluhan tersebut diselingi dengan acara diskusi dan ramah tamah.

Pada saat kegiatan penyuluhan, peserta penyuluhan merespon secara antusias juga pemerintah setempat karena kegiatan yang dilakukan sesuai dengan peraturan RT dan pemerintah daerah. Hal ini dilihat dengan banyaknya pertanyaan yang didiskusikan dan ingin diketahui dengan baik oleh peserta penyuluhan menyangkut pemeliharaan ternak babi.

Kegiatan diakhiri dengan doa yang juga dipimpin oleh salah seorang peserta penyuluhan.

Pada saat kegiatan penyuluhan disepakati beberapa hal menyangkut kegiatan demplot yang harus dilakukan dengan kesepakatan antara ketua kedua mitra dan semua anggota mitra terutama yang tidak memelihara babi atau memelihara babi namun terletak di tanah milik orang lain, sebagai berikut:

a. Pembangunan kandang contoh yang pada mulanya hanya pada dua anggota mitra yang terletak pada satu lokasi yang sama, karena alasan ekonomi dari salah satu anggota msayarakat peternak babi yang bukan anggota mitra sehingga pembangunan kandang contoh juga dilakukan pada lokasi kepala keluarga tersebut.

b. Bagi anggota mitra atau anggota masyarakat peternak babi yang ingin mendapatkan bantuan lubang pembuangan limbah diharapkan segera meminta ijin pada pemilik tanah bersangkutan

c. Bagi anggota kelompok kedua mitra yang tidak memelihara ternak babi atau dulu pernah memelihara tapi tidak memelihara lagi sekarang harus merelakan pembangunannya kepada anggota masyarakat peternak babi lain yang bukan termasuk anggota mitra.

d. Setiap anggota masyarakat peternak atau mitra yang mendapatkan bantuan pembanguna lubang limbah harus menggali lubang pembuangannya masingmasing.

e. Disepakati beberapa lokasi penurunan bahan bangunan untuk memperlancar proses pembangunan kandang dan lubang pembuangan limbah.

f. Disepakati bahwa pembangunan kandang dan lubang pembangunan limbah dipercayakan kepada seorang tukang dan bagi peternak yang ingin mengerjakan 
sendiri pembangunanya maka akan dikenakan biaya pengganti pembangunan. Hal ini dlakukan karena terdapat sebagian anggota masyarakat dan anggota mitra yang tidak dapat membangun atau menggali sendiri karena keterbatasan kemampuan serta kegiatan gotong royong antar semua anggota masyarakat untuk membangun kandang dan lubang pembuangan bersama tidak dapat dilakukan karena masingmasing memilki tanggunjawabnya masing-masing pada lokasinya.

g. Penggalian lubang pembuangan harus sudah selesai paling lambat tiga minggu dari hari penyuluhan.

h. Pelaksanana demplot pakan ternak babi dilakukan pada lokasi kandang contoh pemeliharaan.

\section{Metode Demplot:}

Kegitan demplot dibagi dalam dua kegaiatn yakni:

a. Demplot penyusunan ransum contoh untuk pemelihraan ternak babi sebanyak dua ekor:

Demplot penyusunan ransum dilakukan pada lokasi pertama yakni milik dua orang mitra sekaligus yakni mitra dari kelopok KUB RPI dan ketua kelompok Mitra Rayon 21. Pembangunan kandang sudah dilakukan sejak pencairan dana belum dilakukan dan belum adanya penyuluhan karena dilakukan berdasarkan pendekatan tim dengan kedua ketua kelompok mitra. Alasan pemilihan lokasi ini juga dikarenakan agar mewakili dua kompok sekaligus dan juga untuk memudahkan dilakukan perbandingan pertumbuhan ternak babi pada dua contoh pemeliharaan ternak babi yang menggunakan limbah dapur $100 \%$ dan yang menggunakan limbah dapur $20 \%$ dicampur dengan pakan komplit yang diramu sendiri. Pemeliharan dilakukan selama 50 hari namun pelaksanaan demplot pakan disusun selama tiga bulan pemeliharaan.

b. Demplot pembangunan kandang contoh:

Pembangunan kandang contoh dilakukan pada dua lokasi namun peruntukkannya bagi 3 anggota mitra. Pembangunan kandang contoh pada lokasi kedua tidak memiilki pintu dikarenakan lokasi terletak pada daerah yang sering digenangi air pada saat hujan dan juga karena pembangunan pintu sudah dilakukan pada lokasi kandang 
contoh yang pertama. Selain itu, pembangunan kandang contoh pada lokasi kedua disesuaikan dengam permintaan peternak. Hal ini dikarenakan babi yang dipelihara dalam keadaan bunting sehingga pemabngunan kandnag luasannya diperlebar yang mulanya 1,5 m x 1,5 m menjadi 1,5 m x $2 \mathrm{~m}$ dan lubang pembungan limbah hanya satu lubang dan tidak dibagi menjadi dua karena sempitnya luasan lubang yang digali. Perubahan permintaan ini menyebabkan kurangnya bahan untuk pembuatan tempat penyimpanan pakan dan peternak berjanji akan membuat sendiri dengan menggunakan kayu.

\section{Metode Pendampingan:}

Metode pendampingan dilakukan sejak pembangunan kandang contoh pada lokasi pertama hingga pada saat setelah penyuluhan serta terus dilanjutkan hingga semua kegiatan telah selesai dilakukan sampai pada penyusunan laporan akhir.

Pada saat pedampingan yang biasanya didiskusikan adalah tentang pemeliharaan babi sebagai bibit dan penggemukan serta bagaimana memberi makan babi yang baik serta beberapa hal yang didiskusikan menyangkut peternakan babi.

Capaian Pelaksanaan kegiatan "IbM Desain Kandang Babi Di Perkotaan" sesuai target yang ditetapkan:

\begin{tabular}{|l|l|l|l|}
\hline No & Target & Sebelum & Sesudah \\
\hline 1 & Peningkatan pengetahuan mitra & Pengetahuan masih & Sudah mulai \\
& & sedikit tentang & memperhatikan \\
& & manajemen & pemeliharan ternak babi \\
& & dan dilakukan & manemen pemeliharan \\
ternak babi dengan \\
membangun kandang yang \\
\end{tabular}




\begin{tabular}{|c|c|c|c|}
\hline & & & lainnya \\
\hline 2 & $\begin{array}{l}\text { Peningkatan } 100 \% \\
\text { pengetahuan mitra tentang } \\
\text { dampak limbah terhadap } \\
\text { lingkungan terutama di daerah } \\
\text { perkotaan yang memiliki lahan } \\
\text { yang sempit }\end{array}$ & $\begin{array}{l}\text { Limbah ternak ada yang } \\
\text { dibiarkan saja tanpa } \\
\text { penampungan limbah, } \\
\text { lubang limbah } \\
\text { dibiarkan terbuka dan } \\
\text { tidak bersemen serta } \\
\text { dibiarkan meresapke } \\
\text { dalam tanah dan } \\
\text { lingkungan sekitar }\end{array}$ & $\begin{array}{l}\text { Kandang sudah memiliki } \\
\text { lubang limbah dan dibuat } \\
\text { bersemen sehingga } \\
\text { peresapan tidak terjadi }\end{array}$ \\
\hline 3 & $\begin{array}{l}\text { Peningkatan pengetahuan mitra } \\
\text { tentang penggunaan limbah } \\
\text { rumah tangga dan limbah } \\
\text { rumah makan sebagai pakan }\end{array}$ & $\begin{array}{l}\text { Pakan yang diberikan } \\
\text { hanya limbah dapur } \\
\text { atau bahan pakan } \\
\text { seadanya tanpa } \\
\text { campuran lainnnya } \\
\text { yang sesusia dengan } \\
\text { kebutuhan ternak babi }\end{array}$ & $\begin{array}{l}\text { Limbah dapar sudah } \\
\text { diberikan pada ternak babi } \\
\text { dengan dicampur dengan } \\
\text { bahan pakan lainnya serta } \\
\text { sudah ada tambahan } \\
\text { sumber vitamin dan } \\
\text { mineral misalnya garam. }\end{array}$ \\
\hline 4 & $\begin{array}{l}\text { Dihasilkannya } 100 \% \text { anggota } \\
\text { mitra yang melaksanakan } \\
\text { pemeliharaan ternaknya dalam } \\
\text { kandang yang dilengkapi } \\
\text { dengan tempat penampungan }\end{array}$ & $\begin{array}{l}\text { Masih terdapat peternak } \\
\text { yang tidak memilki } \\
\text { kandang dan lubang } \\
\text { pembuangan limbah }\end{array}$ & $\begin{array}{l}\text { Semua anggota mitra dan } \\
\text { peternak } 100 \% \text { yang } \\
\text { memgikuti penyuluhan } \\
\text { telah memilki kandang dan } \\
\text { lubang pembuangan. }\end{array}$ \\
\hline 5 & $\begin{array}{l}\text { Dihasilkanya minimal } 80 \% \\
\text { anggota mitra yang tidak } \\
\text { menempatkan limbah dapur } \\
\text { dan limbah rumah makan } \\
\text { sebagai pakan ternak babi di } \\
\text { dalam rumah. }\end{array}$ & $\begin{array}{l}\text { 100\% peternak babi } \\
\text { menempatkan makanan } \\
\text { babi di dalam rumah }\end{array}$ & $\begin{array}{l}\text { Terdapat } 100 \% \text { mitra yang } \\
\text { sudah menempatkan pakan } \\
\text { babi di luar rumah induk }\end{array}$ \\
\hline 6 & $\begin{array}{l}\text { Dihasilkannya } 80 \% \text { anggota } \\
\text { mitra yang membangun }\end{array}$ & $\begin{array}{l}\text { Terdapat } 20 \% \text { anggota } \\
\text { mitra yang membangun }\end{array}$ & $\begin{array}{l}\text { Terdapat } 100 \% \text { anggota } \\
\text { mitra yang sudah }\end{array}$ \\
\hline
\end{tabular}




\begin{tabular}{|c|c|c|c|}
\hline & $\begin{array}{l}\text { kandang dengan desain lantai } \\
\text { kandang yang baik. }\end{array}$ & $\begin{array}{l}\text { kandang dengan desain } \\
\text { lantai miring }\end{array}$ & $\begin{array}{l}\text { membangun lantai } \\
\text { kandang dengan } \\
\text { kemiringan yang baik }\end{array}$ \\
\hline 7 & $\begin{array}{l}\text { Peningkatan minimal } 80 \% \\
\text { respon baik dari anggota } \\
\text { masyarakat sekitar terhadap } \\
\text { pemeliharaan ternak. }\end{array}$ & $\begin{array}{l}\text { Terdapat } 100 \% \text { respon } \\
\text { masyarakat yang tidak } \\
\text { menyukai pemeliharaan } \\
\text { ternak babi karena bau } \\
\text { yang tercium }\end{array}$ & $\begin{array}{l}\text { Terdapat } 80 \% \text { anggota } \\
\text { masyarakat yang dapat } \\
\text { menerima pemeliharaan } \\
\text { ternak babi karena bau } \\
\text { yang tercium sudah } \\
\text { berkurang }\end{array}$ \\
\hline 8 & $\begin{array}{l}\text { Peningkatan produktivitas } \\
\text { ternak babi contoh yang } \\
\text { mengonsumsi ransum yang } \\
\text { menggunakan limbah dapur } \\
\text { dan rumah makan }\end{array}$ & $\begin{array}{l}\text { Pertumbuhan ternak } \\
\text { babi lambat PBB } \\
0,2 / \mathrm{kg} / \text { hari }\end{array}$ & $\begin{array}{l}\text { Pertumbuhan ternak babi } \\
\text { cepat PBB 0,4 kg/ekor/hari }\end{array}$ \\
\hline 9 & $\begin{array}{l}\text { Peningkatan respon } \\
\text { pemerintah setempat terhadap } \\
\text { kegiatan pemeliharaan ternak } \\
\text { babi }\end{array}$ & $\begin{array}{l}\text { Kurang setuju } \\
\text { pemeliharaan ternak } \\
\text { babi karena polusi bau } \\
\text { yang dihasilkan }\end{array}$ & $\begin{array}{l}\text { Menyetujui pemeliharaan } \\
\text { ternak babi asalkan } \\
\text { kandang dibersihkan dan } \\
\text { terdapat lubnag } \\
\text { pembuangan limbah }\end{array}$ \\
\hline 10 & $\begin{array}{l}\text { Peningkatan minimal } 100 \% \\
\text { anggota mitra yang tidak } \\
\text { mengalirkan limbah kandang } \\
\text { ternak babi ke dalam saluran } \\
\text { pembuangan air umum. }\end{array}$ & $\begin{array}{l}\text { Terdapat } 10 \% \text { anggota } \\
\text { mitra yang } \\
\text { menaglairkan limbah ke } \\
\text { saluran umum }\end{array}$ & $\begin{array}{l}\text { 100\% anggota mitra sudah } \\
\text { membuang limbah ke } \\
\text { lubang pembuanagn } \\
\text { limbah masing-masing }\end{array}$ \\
\hline 11 & $\begin{array}{l}\text { Membangun persaudaraan } \\
\text { iman antar anggota yang } \\
\text { memiliki keyakinan berbeda. }\end{array}$ & $\begin{array}{l}\text { Hubungan antara kedua } \\
\text { kelompok tidak terlalu } \\
\text { dekat (kurang bertegur } \\
\text { sapa) }\end{array}$ & $\begin{array}{l}\text { Hubungan persaudaraan } \\
\text { semakin baik dan akrab }\end{array}$ \\
\hline 12 & Polusi bau dari kandang babi & $\begin{array}{l}\text { Bau yang tercium } \\
\text { sangat menusuk hidung }\end{array}$ & $\begin{array}{l}\text { Bau yang tercium } \\
\text { berkurang } 90 \% \text {, terutama }\end{array}$ \\
\hline
\end{tabular}




\begin{tabular}{|l|l|l|}
\hline & & $\begin{array}{l}\text { jika digunakan juga } \\
\text { produk EM4 }\end{array}$ \\
\hline
\end{tabular}

Berdasarkan hasil kegiatan yang dilakukan maka luaran yang sudah dihasilkan adalah:

- Desain perkandangan ternak babi yang dilengkapi dengan lubang pembuangan limbah dan tempat untuk menyimpan pakan yang terletak langsung disamping petak kandang.

- Dihasilkannya lubang pembuangan limbah ternak babi pada beberapa lokasi pemeliharaan ternak baik mitra maupun masyarakat peternak babi.

- Pemberian ransum contoh untuk ternak babi untuk mengukur pertumbuhanya dengan hasil yang baik.

\section{SIMPULAN DAN SARAN}

\section{Simpulan}

Berdasarkan hasil kegiatan, disimpulkan bahwa kegiatan mencapai target $100 \%$ untuk pembangunan kandang dan pembuangan limbah, kegiatan yang dilakukan sesuai dengan metode yang direncanakan, serta peningkatan pengetahuan masyarakat dan kurangnya polusi bau yang ditimbukan .

\section{Saran}

Berdasarkan kesimpulan disarankan agar kegiatan selanjutnya pada lokasi lain dan menggunakan juga produk EM4 untuk menghilangkan bau. 


\section{DAFTAR PUSTAKA}

Eusebio, J.A. 1988. Pig Production In The Tropics. Intermediate Tropical Agriculture Series. Longman Group, Ltd. Hongkong.

Moata R. S. M., 2004. Potensi Pemanfaatan azolla dalam Menunjang Pertanian Berkelanjutan di Nusa Tenggara Timur. Jurnal Partner Buletin Pertanian Terapan. Edisi khusus. hal. 39.

Wea. R., 2007. Manajemen Pemeliharaan Ternak Babi Lokal di Kecamatan Kelapa Lima Kota Kupang. Jurnal Partner Buletin Pertanian Terapan. hal. 128. 